\title{
LOKALNE PRIPOVEDI Z BISTRIŠKEGA POHORJA MED KULTURNO DEDIŠČINO IN LITERARIZACIJO
}

\author{
BARBARA IVANČIČ KUTIN IN MONIKA KROPEJ TELBAN
}

Predstavitve pripovednega izrocila in situ, tj. v njegovi kulturni krajini, so danes razmeroma pogoste. Kot kulturna dedišcina okolja so lokalne pripovedi vključene $v$ pedagoške dejavnosti, turistično in kulturno ponudbo, pa tudi v komercialne namene. Pripovedi, ki se povezujejo $z$ desetimi lokacijami na območju Bistriškega Pohorja, so bile vključene $v$ raziskovalni projekt, na osnovi raziskave pa so bile pozneje v literarizirani oz. reinterpretirani obliki objavljene v vodniku. Postopek pretvarjanja slovstvene folklore (umetnosti govorjenega jezika) v literaturo v vsakem primeru povzroči manjše ali večje oddaljevanje od izvirne oblike iz ust pripovedovalca na terenu. Za znanstveno raziskovanje je uporabno le gradivo $v$ izvirni obliki, dokumentirano $s$ čim natančnejsimi metapodatki. V̌́lanku so predstavljene še neobjavljene in težje dostopne pripovedi, ki so bile podlaga knjižni literarizaciji. Pri tem so obravnavane tudi metode terenskega dela in značilnosti posamičnega zapisa oz. transkripcije. Poudarjene so tudi razlike med današnjim terenskim in starejsim zapisanim gradivom.

Ključne besede: Slovenska Bistrica, folklora, povedke, pravljice, mitska krajina, Pohorje
Presentations of narrative folklore in situ, i.e. in their cultural landscape, are relatively common today. As the intangible heritage of an environment, they are included in educational activities, tourist and cultural offers, and are increasingly exploited also for commercial purposes. For example, the narrative folklore in the Pohorje area above Slovenska Bistrica was included in a research project, and the tales associated with ten sites in the area have been included in a guidebook in literalised and reinterpreted form. The process of "ironing" the narratives by transforming folklore (the art of spoken language) into literature means a greater or lesser deviation from the original narrative. Only material in its original form with the most accurate metadata is useful for scholarly research. The article presents the unpublished and less accessible units that formed the basis of literalisation. The method of field research, and characteristics of the individual transcriptions are described, and the differences between present-day field material and the older written material are also highlighted.

Keywords: Slovenska Bistrica, folklore, folktales, fairy tales, mithycal landscape, Pohorje

\section{UVOD}

Raziskovanje nesnovne kulturne dediščine in še posebej pripovedne kulture se vedno bolj osredinja na pripovedi v prostoru - in situ. Danes bolj kot o zgodbah lahko govorimo o diskurzih v smislu govora ali razpravljanja o določenem dogodku ali izročilu. Willem de Blécourt je diskurz definiral kot koherenten sistem konceptov, zgodb in dejanj (Blécourt, 2013: 363, 369, po Mencej, 2020: 138). Pri tem, kako je v pripovedni kulturi strukturiran prostor, je pomembno vedeti, da pripovedništvo ni statično, spreminjanje poteka na diahroni in sinhroni ravni, saj na spremembe močno vplivata kraj in čas oziroma socialno in kulturno okolje, v katerem ljudje živijo. Na spremembe pripovednih vsebin vplivajo tudi načini prenašanja, ki so se na prehodu v tretje tisočletje močno spremenili in so se, predvsem zaradi svetovnega spleta, še mnogo bolj globalizirali. Ljudje, ki pripisujejo vsebinski pomen prostoru, oblikujejo sebi pomembne kulturno-pomenske kraje in ti kraji imajo tudi 
odločilno vlogo pri njihovem identifikacijskem procesu. Ülo Valk in Daniel Sävborg sta ugotovila, da so s prostori oz. pokrajino povezana različna pričevanja (angl. place-lore), saj so kraji več kot le geografska lokacija, so namreč tudi kraji spominov (angl. sites of memory) in prizorišča izjemnih srečanj, kar odseva v pripovedovanju zgodb, ki simbolizirajo prostor (Valk, Sävborg, 2018: 7-20). Kraji spomina spodbudno delujejo na povečano pozornost obiskovalcev, hkrati pa zgodbe o tem ali na tem prostoru pripomorejo, da obiskovalec intenzivneje doživi pripoved ter si tako kraj, doživetje in s tem povezano zgodbo bolj vtisne v spomin. ${ }^{1} \mathrm{Na}$ ta način se povrnejo v mentalni diskurz ljudi (Koski, 2016: 32) in pripovedovanje teh zgodb vpliva na način kognicije, ki izraža določen pogled na svet. Pripovedi torej lahko postavimo na kognitivni zemljevid doživetij, osebnih zgodb, izročil, razmišljanj in diskurzov ljudi. Estonska folkloristka Reet Hiiemäe ugotavlja, da je v pripovednem izročilu mogoče ustvariti mentalni zemljevid, ki v določeni skupnosti postavi pripovedi v prostor in jih približa ljudem (Hiiemäe, 2016: 179-18). Skladno s tem tudi islandski folklorist Terry Gunnell meni, da pripovedi v krajini služijo kot nekakšen zemljevid: na eni strani ljudi spominjajo na krajevna imena in poti ter dajejo zgodovinski pomen okolju, hkrati pa ga naseljujejo z duhovi in raznimi drugimi bajeslovnimi liki. $\mathrm{Na}$ ta način opominjajo ljudi na časovne in fizične meje njihove eksistence, na vprašanja življenja in smrti ter liminalnosti v prostoru (Gunnell, 2008: 15).

Da bi lahko pripovedi postavili v prostor, je potrebno poznavanje lokalnega izročila z različnih vidikov, npr., historičnega (lokalno kot tudi širše), žanrskega in jezikoslovnega. Upoštevati je treba kar se da celosten diahroni in sinhroni kontekst, vselej z upoštevanjem lokalnega prebivalstva, njihovih spominov, izkušen, zgodbe. Brez tega se lahko zgodi, da je lokalna pripovedna kultura uprostorjena na anahronističen in selektiven način, strukturiranje krajev spomina in pripovednega izročila $\mathrm{v}$ prostoru pa ni avtentično. Zato je pri takih projektih pomembno sodelovanje strokovnjakov (Ivančič Kutin, Kropej Telban, 2018). Poleg (re)interpretacij in poustvarjanja pripovedne dediščine, ki še ima stik z izročilom, se, predvsem v komercialnih produktih, namreč pojavljajo tudi povsem novi konstrukti, ki iz izročila ohranjajo samo še ime in izbrane konotacije imena (Ivančič Kutin, 2017).

\section{PRENOS USTNO IZVEDENE PRIPOVEDI V PISNI KOD}

Sodelavci Inštituta za slovensko narodopisje ZRC SAZU smo bili povabljeni k sodelovanju v slovensko-hrvaški bilateralni projekt Živa Coprnija, ${ }^{2}$ ki naj bi z visoko kakovostnimi turističnimi in edukativnimi produkti pripomogel $\mathrm{k}$ spoznavanju pripovedne dediščine na

1 To je pokazala tudi raziskava med bovškimi osnovnošolci: ko je šola vključila v pedagoški proces poslušanje avdio-posnetkov lokalnih pripovedi v narečju in situ, se je pri učencih bistveno izboljšalo poznavanje lokalnega pripovednega izročila (Ivančič Kutin, 2019).

2 European Interreg project Slovenia - Croatia (Living Magic - Živa coprnija - Živa štrigarija, 20172019), Financirano iz European Regional Development Fund. 
Bistriškem Pohorju in v hrvaški Istri. Naša naloga je bila najti ustrezno pripovedno gradivo, na podlagi katerega bi z literarno reinterpretacijo pisatelja in kakovostnimi ilustracijami pripravili vodnik na estetsko visoki jezikovni in likovni ravni. "Surovi« terenski posnetki/ zapisi so bili zaradi ustnega prenosa in s tem sinkretičnosti za namen poljudnega in estetskega branja neprimerni. Ustno pripovedovana zgodba poleg besedila namreč vključuje še oblikovanje z glasom, mimiko in kinetiko pripovedovalca, na pripoved pa vplivajo še številne druge okoliščine.

Pri prenosu v pisni kod pa prvotno ustna pripoved ostane brez bistvenih elementov, zato le senca tistega, kar je mogoče s poslušanjem (in gledanjem!) doživeti ob pripovedovanju v živo (Ivančič Kutin, 2011). Celo pri zapisu za znanstveno rabo gre za vrsto kompromisov pri transkripciji; pri prirejanju folklornih besedil za širše občinstvo in z različnimi nameni pa je zaradi načina, kako ta besedila obstajajo - to je v večno spreminjajočem se vsebinskem in jezikovnem uglaševanju zgodbe in pripovedovalca po eni strani ter pripovedovalca in poslušalcev na drugi strani - izziv, ki se izmika pristopu, ki bi bil najbolj "pravi« in tudi dokončen, kar naj bi bila najbolj "prava« realizacija (Štefan, 2019a: 244, 245). Postopek prenosa slovstvene folklore (umetnosti govorjenega jezika) v literaturo (pisni jezik) torej v vsakem primeru povzroči manjše ali večje oddaljevanje od izvirne (ustne) oblike; oddaljenost pa je odvisna od poznavanja koncepta slovstvene folklore, jezikovne tenokočutnosti prirejevalca, njegove želje, da ostane v stiku s prvotnim zapisom, in še česa. Ti pristopi in načini so že zunaj znanosti, saj segajo v umetnost; izjema so osebe, ki so hkrati znanstveniki in umetniki. ${ }^{3}$

Tudi pri projektu Živa coprnija se je pristojnost strokovnjakov sklenila z zagotovitvijo ustreznega terenskega gradiva, evidentiranjem bajnih bitij in drugih likov ter izborom zgodb, ki se v lokalnem izročilu najbolj povezujejo z izbranimi desetimi kraji.

\section{EVIDENTIRANJE IN HISTORIČNI PREGLED PISNEGA GRADIVA}

Gradivo smo iskali po različnih pisnih virih: 1. v knjižnih zbirkah, 2. v časopisih objavah od druge polovice 19. stoletja, 3. pregledali smo rokopisne vire $\mathrm{v}$ arhivih različnih ustanov ${ }^{4}$ ter 4. tipkopise raznih projektnih in raziskovalnih nalog ter tematske brošure učencev, dijakov, učiteljev, tečajnikov za turistične vodnike ipd. Pri tem se nismo omejili zgolj na Bistriško pač pa na celotno Pohorje.

Med starejšimi zapisovalci je treba omeniti Lovra Stepišnika, mlinarja in prvega slovenskega potujočega knjižničarja iz Zgornje Ložnice pri Slovenski Bistrici, ki je v Kmetijskih

3 V Sloveniji npr. Milko Matičetov in Anja Štefan.

4 V arhivu Inštituta za slovensko narodopisje so mdr. terenski zvezki Milka Matičetovega iz leta 1959; $\mathrm{v}$ arhivu Slovenskega etnografskega muzeja je bil pregledan obsežen fond zapisov in drugih dokumentov (fotografije), ki so jih na Pohorju pridobili sodelavci muzeja v 14-dnevni raziskavi na južnem Pohorju v letu 1963; v knjižnici in šolah v Slovenski Bistrici smo našli številne rokopise in tipkopise. 
in rokodelskih novicah v letih 1864 in 1869 objavil nekaj pohorskih pripovedi (Stepišnik, 1864, 1869). Pred njim je nekaj drobcev pohorskega izročila objavil tudi Davorin Trstenjak (Terstenjak, 1859). Istega leta je v Kmetijskih in rokodelskih novicah neznanec pod psevdonimom Fr. Pohorski (1859) pisal o velikanu Vouvelu; leta 1860 pa je bil objavljen v Slovenskem glasniku prispevek O Vetrihu, Vetronu. Neznani zapisovalec je pod psevdonimom -c- leta 1884 objavil v časopisu Ljudski glas prispevek o škopnjeku, nočnem lovcu in lesnem možu (-c-, 1884). Josip Pajek je v knjigi Črtice iz duševnega žitka štaj. Slovencev pisal o Vehtri babi in o Šentu (Pajek 1884: 2, 226).

Slovstveno izročilo je zbiral tudi Filip Miklavec (1863-1910), ki je pod psevdonimom I. Vrhovski v Domu in svetu leta 1903 objavil kratko pohorsko pravljico "Truojni odgovor" (ATU ${ }^{5} 921$ »Kralj in kmetov otrok«), zapisano je bilo predvidoma v Zgornji Orlici pri Ribnici na Pohorju (Miklavec 1903).

Med starejšimi zapisovalci pripovedi na Pohorju sta bila učitelja Josip Brinar (1874-1959), ki je leta 1933 izdal zbirko Pohorske bajke in povesti (1933), in Jože Tomažič (1906-1970), ki je objavil kar tri zbirke: Pohorske pravljice (1942), Pohorske bajke (1943) in Pohorske legende (1944).

Velike zasluge za ohranitev pohorskega pripovednega izročila ima ljubiteljski arheolog Paul Schlosser, ki je kot mlad oficir avstrijske armade v Mariboru v letih 1910 in 1911 zbiral pripovedi s Pohorja, saj se je zanimal za zgodovino, arheologijo in pripovedno izročilo (Schlosser 1912). Njegova zbirka Bachern-Sagen je posthumno izšla pri avstrijskem etnografskem muzeju na Dunaju leta 1956, slovenski prevod Pohorske pripovedke je bil izdan leta 2015. Schlosserjevo gradivo je dragocen vir kljub nekaterim pomanjkljivostim, kakršna je npr. ta, da nikjer niso navedena slovenska krajevna imena, saj je v uvodnem besedilu ravnatelj dunajskega etnografskega muzej Leopold Schmidt poudaril nemški značaj tega izročila, kar je čutiti tudi iz opomb, ki jih je na urednikovo prošnjo napisala etnologinja Elfriede Moser Rath. Vse to je spodbudilo etnologa in jezikoslovca Milka Matičetovega, da je s hrvaško folkloristko Majo Bošković-Stulli napisal kritiko tega dela (Matičetov, Bošković-Stulli, 1958).

Matičetov je leta 1957 tudi sam raziskoval na Pohorju, kjer je v Legnu in v Golavabuki pri Slovenj Gradcu ter okolici zapisal tri pravljice in nekaj povedk, toda gradiva ni objavil. Zapiski so iz dveh terenskih zvezkov, ki so v Inštitut za slovensko narodopisje ZRC SAZU prišli z njegovo zapuščino. ${ }^{6}$ Pozneje je RTV Slovenija leta 1967 za serijo "Slovenski pravljičarji« posnela na Pohorju tudi dokumentarni film, v katerem je pripovedoval pravljičar Gustl Fišer - Grabnerjev iz Legna pri Slovenj Gradcu pravljici »O treh godcih" (ad ATU 470A "Don Juan« + ad ATU 471A »Menih in ptič») in "O tobaku» (ad ATU 1091A »Ugibanje imena vragove skrivnostne rastline«).

5 ATU je mednarodna klasifikacija pravljic po pravljičnih tipih po sistemu, ki so ga izdelali Antti Aarne, Stith Thompson in Hans-Jörg Uther.

6 Dve pravljici sta bili objavljeni (Kropej Telban, Dapit, 2018: 92-95; Štefan, 2019a: 215-220). 
Leta 1968 je Oskar Hudales v zbirki Zlati krompir objavil pohorske pripovedke, ki pa jih je v precejšnji meri povzel po že objavljenih virih - predvsem iz že omenjene knjige Paula Schlosserja. V zadnjih desetletjih sta na Pohorju zbirala pripovedi Anton Gričnik (1995, 2015) in Andrej Gulič (2006).

Ohranili so se tudi zapisi pregovorov s Pohorja, ki jih je zbral Janez Zorman v akciji Kluba Nedeljskega "Zbirajmo stare pregovore« leta 1983. V akciji, katere pobudnik pri tedniku Družina leta 2000 je bil Bogdan Dolenc, sta pregovore s Pohorja zbrala tudi Anton Gričnik in Bernard Režek (Gričnik, Režek, 2000).

Ljudske pesmi z napevi je v obsežni zbiralni akciji Ljudska pesem v Avstriji leta 1910 zbral trgovec Jožef Lešnik iz Kebla na Pohorju. Objavo je načrtovalo Avstrijsko ministrstvo za uk in bogočastje na Dunaju, ki je za urednika slovenskega dela zbirke v Odboru za zbiranje slovenskih narodnih pesmi leta 1904 izbralo Karla Štreklja. ${ }^{7}$ Jožef Lešnik je prispeval številne zapise, ki pa niso bili objavljeni, saj je avstro-ogrska monarhija razpadla pred dokončanjem dela.

\section{TERENSKE RAZISKAVE PRIPOVEDI NA BISTRIŠKEM POHORJU}

$\mathrm{V}$ času projekta smo sodelavci Inštituta za slovensko narodopisje med udeleženci delavnic in drugih izobraževanj preverjali, koliko je izročilo, ki je objavljeno v omenjenih virih, še poznano. Pokazalo se je, da učitelji in kulturni delavci razmeroma dobro poznajo in tudi vključujejo v svoje aktivnosti zlasti pripovedi iz Tomažičeve zbirke (1943); kot že omenjeno, so te literarizirane, torej avtorsko dodelane, kar je s strokovnega vidika avtentičnosti sporno. Gradivo in druge objave pa so malo poznane in upoštevane. Po določitvi desetih lokacij za vodnik (1. Slovenska Bistrica, 2. Bistriški vintgar, 3. Ančnikovo gradišče, 4. cerkev sv. Urha nad Velikim Tinjem, 5. Trije kralji, 6. Črno jezero,7. Šmartno na Pohorju. 8. Šetorov mlin, 9. Tinje, 10. Kebelj) smo se odpravili tudi na teren. Za nekatere od teh krajev v virih ni bilo gradiva in ga je bilo treba šele poiskati, pri drugih je bila preverjena živost že zapisanih pripovedi, ob tem pa je bilo dokumentirano še mnogo drugega pripovednega gradiva $\mathrm{v}$ povezavi z njimi. Na terenu se je pokazalo, da starejši sogovorniki še vedo povedati zgodbe, ki se navezujejo na kulturno krajino in kraje Bistriškega Pohorja. To so povečini pripovedi o nekdanjem življenju v tem prostoru (preživetje, šege, verovanja, zdravljenje, česa so se bali, česa veselili idr.); marsikatera informacija je dragocen drobec, ki dopolnjuje podobo lokalne zgodovine in etnografije tega prostora. Lokalnih folklornih pripovedi, kot so pravljice in povedke, pa so se ljudje - z nekaj odličnimi in solidnimi izjemami - spominjali zgolj $\mathrm{v}$ fragmentih. Na terenu smo posneli tudi nekaj vizualnih zapisov pripovedi (Pripovedi z Bistriškega Pohorja I-IV, 2018).

\footnotetext{
Več o tej zbiralni akciji gl. Traditiones 34 (1), 2005.
} 
$S$ pridobljenim gradivom je bil zarisan zemljevid lokalnega izročila, na podlagi katerega je nato nastajal vodnik po izbranih krajih. Z njim obiskovalci spoznavajo zgodbe na kraju samem, kar je del doživetja, ki pripomore k večjemu (za)pomnjenju zgodbe same in prostora hkrati. Gradivo, zbrano na terenu in v manj dostopnih virih, je objavljeno v prilogi »Neobjavljeno in težje dostopno pripovedno gradivo z Bistriškega Pohorja«, drugi viri so navedeni le $\mathrm{z}$ referenco.

\section{SKLEPNE MISLI}

Gradivo, na osnovi katerega strokovnjaki lahko raziskujejo in predstavijo pripovedno kulturo določenega prostora oziroma območja, mora biti čim bolj avtentično zapisano, tako kot so pripovedovali ljudje. Temu načelu je sledila tudi raziskava pripovednega izročila na Pohorju, čeprav je bilo pri projektu Živa coprnija delo strokovnjakov (pridobitev gradiva v virih in na terenu ter evidentiranje bajnih bitij na tem območju) zgolj podlaga za prirejeno literarno, izobraževalno in turistično rabo. Takšno izhodišče je omogočalo, da lokalne zgodbe ne bi bile prirejene ali na novo interpretirane zgolj v smislu komercializacije, katere učinek je pogosto nekakšna legendarna fiktivna pokrajina, nastala s prikrojevanjem folklornega izročila za turiste (Bacchilega, 2007).

Cilj naše nadaljnje, od omenjenega projekta neodvisne folkloristične raziskave, pa je osebne zgodbe in folklorne pripovedi, spomine in druga pripovedovanja ljudi ustrezno postaviti v mitopoetsko strukturirano pokrajino in na kognitivni zemljevid Bistriškega Pohorja. Tako evidentirane pripovedi drugih zapisovalcev kakor tiste, ki smo jih zbrali na terenu, omogočajo različne primerjave, npr., da danes zgodbe niso več tako kompleksne, kar se kaže tudi v umanjkanju žanra pravljice, tudi motivi povedk se krčijo, včasih zgolj na enega, povedane so fragmentarno ali v obliki pogovora med dvema ali več udeleženci, niso tako konsistentne, kakršne so jih dokumentirali zapisovalci ob koncu 19., na začetku in v prvi polovici 20. stoletja. Anahronizme in selektivne konceptualizacije tradicije, ki jih lahko opažamo v gradivu, je treba razumeti skozi proces izumljanja tradicije (Bendix, 1989, po Šešo, 2020: 186). Za trajen in vzdržen razvoj teh ali drugih krajev in ohranjanje pripovednega izročila $v$ prostoru je treba upoštevati ne le mnenja in dognanja raziskovalcev, pač pa tudi lokalno prebivalstvo, torej tako etski kot emski vidik v odnosu do pripovedne kulturne dediščine v prostoru. Prav domačini bodo namreč vplivali na razvoj in obstoj pripovednega izročila - na ohranitev, pozabo ali nastanek novega.

Ko bo bralcem prišla v roke knjiga z avtorsko interpretacijo Dušana Šarotarja (Cunta, 2019), bodo objavljene zgodbe morda doživele podoben odmev kakor pripovedi, ki sta jih pred desetletji objavila Jože Tomažič in Josip Brinar - njune interpretacije so dobile mesto v izročilu. Pri dediščini gre namreč za »sedanje preteklosti«, ki so vedno produkt pogledov iz sedanjosti na preteklost in se ne morejo izmakniti niti ideološkemu primežu niti političnim interesom, kar se v zadnjem času pogosto dogaja (Slavec Gradišnik, 2014; 
Ivančič Kutin, Kropej Telban, 2020: 172-173). Poleg poudarjanja dediščine za kulturno identiteto se postavljanje pripovedi v prostor najnazorneje kaže v poudarjanju dediščine za ekonomsko in družbeno rast.

\section{NEOBJAVLJENO IN TEŽJE DOSTOPNO PRIPOVEDNO GRADIVO Z BISTRIŠKEGA POHORJA}

$\mathrm{V}$ razdelku z gradivom je predstavljenih 33 enot, ki smo jih predlagali za vsako od desetih lokacij. 27 pripovedi je objavljenih v celoti (neobjavljene in v težje dostopnih virih), šest pa le $\mathrm{z}$ navedbo vira. $Z$ objavo na enem mestu bo olajšan dostop do gradiva raziskovalcem in drugim zainteresiranim.

\section{SLOVENSKA BISTRICA}

\section{Bela dama z gradu Slovenska Bistrica}

Nekoč, že davno, je v Bistriškem gradu živel zelo krut grof. Grdo je ravnal z ljudmi, neprestano se je izživljal nad vsemi, še posebej pa nad svojo ženo. Nekega dne jo je dal živo zazidati v steber, ki je bil tedaj še del kapele svete Ane, danes pa je to vogalni steber arkad na dvorišču gradu. Zazidano grofico so hranili skozi majhno lino, dokler so še slišali njen glas.

In čeprav je že dolgo tega, lahko njen duh mimoidoči še vedno začuti, ko gre ponoči mimo tega stebra. V kraju krožijo tudi zgodbe, da se njen duh ne le čuti, pač pa tudi prikazuje na dvorišču gradu. Marsikdo je že, ko je šel ponoči tam mimo, videl belo prikazen.

(Vir: Različni pripovedovalci. Posnela: Barbara Ivančič Kutin, okolica Slovenske Bistrice, 2018.)

\section{Zakaj ne gre železnica skozi Bistrico}

Nekoč so bili drugačni časi. Bila je revščina. Prišlo je včasih tako daleč, da je bil hleb kruha več vreden kot njiva. Takrat so mnogi živeli od furanja; to so bili furmani ali vozarji. V času, ko se je tu mino Bistrice gradila železnica, so bile pošte v privatni lasti. Ti privatniki so imeli konje za pošto in tudi sicer so prevažali. In takrat je bilo v Bistrici znano ime neki Formaher. Bil je župan in lastnik pošte, zelo vpliven, zato je dosegel, da je šla železnica dva kilometra mimo, ker je vedel, da bo sicer izgubil delo. Pa ga je potem kljub temu izgubil.

(Vir: Gričnik, 2015: 28.)

\section{Kurja čarovnica (Zgornja Bistrica)}

$\mathrm{Na}$ Zgornji Bistrici je živela stara ženska sama s kokošmi in psom. Z živalmi se pogovarja kot z ljudmi ter lepo skrbi zanje. Gostilniška nora dekla pride k njej po jajca in vse, kar ji starka pove o živalih, razume po svoje ter pove naokrog. Vaščani jo zmerjajo s čarovnico. Pride župan, ženici postavi vprašanja. Starka jim vse razloži ter se reši suma, da je čarovnica.

(Vir: Tomažič, 1943: 173.) 


\section{BISTRIŠKI VINTGAR}

\section{Vodovnik ugrabi pastiričko.}

(Vir: Tomažič, 1943: 31.)

\section{Sankanje in spravljanje lesa po riži}

Holcarji so bili sekači in vozači. Sekači so sekali, vozači pa so s sankami vozili les do riže aoz. do žag, tam, kjer riž ni bilo. Bistriška riža je bila $10 \mathrm{~km}$ dolga in kakih $70 \mathrm{~cm}$ široka. Speljana je bila ob potoku, ponekod tudi več metrov visoko, celo na stojalih. Riženpartije so bile najete skupine delavcev - največkrat niso bili stalno zaposleni - ki so plavili les, ko se je les spuščalo po riži. So stali na vsake 100 metrov ob riži, (odvisno od zahtevnosti terena), saj je veliko hlodov odletelo iz vodnega korita in jih je bilo treba spravljali nazaj vanj, če se je dalo. Velikokrat so dovajali dodatno vodo iz bližnjega potoka Bistrica. Bilo je tudi veliko nesreč. Poškodbe so zdravili največkrat kar doma, saj je bil dostop v dolino otežkočen. Največ nesreč je bilo pri sankanju hlodovine. Jaz sem te sanke videl, bile so velike, imele so 2 prečnika, na sprednjem je sedel delavec, zadaj na zadnji prečnik so naložili hlode. Sanke so imele na vsaki strani po eno ročico. Na ene sanke so naložili po kubik in pol lesa, to je približno pet do šest hlodov. Tako so vozili samo pozimi. Ko je drevje brez listja, se je sekalo. Hlodi so ležali po vsem gozdu. Potem so prišli sankači, ti so bili večji del najprej sekači ,pozneje pozimi pa sankači in večinoma redno zaposleni. Spredaj je sedel človek, obut v gojzarje in vozil, zaviral (bremzal) pa je samo z nogami. To je bilo težko opravilo; tukaj je bilo tudi največ nesreč. Ko so se sanke preveč zagnale in ni mogel dovolj uspešno zavirati ( bremzati), je koga tudi povaljalo. $S$ sankami so spravljali hlode do riže ali pa do žag. Grof Attems je dal izdelati rižo od Slovenske Bistrice do Močnika leta 1905, potem jo je 20 let pozneje še podaljšal, je šla do Majsterhavza, holcarkega naselja. Riža je šla ob potoku Bistrica, kjer je bila voda, kasneje še do Pevčeve žage. Bistriške riže ni več. Ukinjena je bila leta 1955 in je propadla. Ostanke ruške riže ob potoku Lobnica sem še videl v razvalinah. Zgrajena je bila najprej za potrebe velike Vivatove glažute (steklarne) v Rušah.

Spodaj, v Slovenski Bistrici (Zgornja Bistrica) na koncu korit za plavljenje je bila riža malo dvignjena, da so leteli hlodi kot po skakalnici. Tam so morali delavci zelo paziti. Ni bilo takrat telefonov, da bi se poklicali, da zdaj prihaja hlodovina. Zato so imeli dokaj natančne urnike. Vsaj $2 \mathrm{x}$ na teden so ob določeni uri plavili hlodovino, drva ipd.

(Vir: Arhiv ISN ZRC SAZU. Povedal Stane Gradišnik. Posnela Barbara Ivančič Kutin, 16. 1. 2018, Urh na Pohorju.)

\section{Kurja vas}

Kurja vas je bil zaselek treh, štirih hišs, kjer so živeli stalno zaposleni gozdarji (holcarji) grofa Attemsa, tam je imel grof Attems tudi vikend. Taki zaselki so bili še Majsterhaus, Bajgot. Žene iz Kurje vasi so s srpom nabirale v gozdu travo plajševko, iz katere so pletle kite, podobne vrvem. Te kite so služile za vzdrževanje korit, iz katerih je bila zgrajena riža. Z njimi so zamašili razpoke v koritu, da voda ni odtekala, ko so les plavili po rižah. Vaščani holcarskih vasi se niso z dolinci veliko družili. Enkrat, dvakrat na mesec so šli, v glavnem žene, $v$ dolino, da so prinesle fasengo. 
(Vir: Arhiv ISN ZRC SAZU. Povedal Stane Gradišnik. Posnela Barbara Ivančič Kutin, 16. 1. 2018, Urh na Pohorju.)

\section{ANČNIKOVO GRADIŠČE}

\section{Rojenice}

Živele so v starih časih v votlinah pohorskih gor Rojenice ali divje žene. One so naznanjale vreme, napovedovale čas za dobro setev, in tudi skoraj vsaki noseči ženi in novorojenemu otroku prerokovale njegovo prihodnje življenje. Posebno rade so prebivale v votlinah landeške gore in pod nekdanjim gradom nad Slovensko Bistrico.

Mnogo pravljic si pripoveduje preprosto ljudstvo o Rojenicah in nekaj jih bom tukaj zapisal:

Enkrat zgodaj v pomladi, ko je še debeli sneg zemljo pokrival, začne Rojenica klicati: »Kmet sej bob!« Kmet gre bob sejat, pa ves se mu potaka v neko globoko jamo. Nevoljen reče kmet Rojenici: "Sejal sem ga , pa žeti mi ga ne bo treba.« Ona pa mu odvrne: „Kjer si ga sejal, tam ga boš žel«; in zares, toliko je zraslo boba, da ni vedel, kam bi ga shranil.

Drugikrat ravno na binkoštno nedeljo zgodaj zjutraj stopi Rojenica iz votline, in oziraje se po zraku reče: "Ko bi zdaj kmet proso sejal, dobil bi ga stotero." Neki kmet, ki je to slišal, vse svoje nezorane in neobsejane snjiv s prosom poseje, in dobil ga je stotero.

Pa tudi burke so Rojenice rade vganjale s kmeti. Tako zakliče enkrat Rojenica: „Kmet sej bob!« pa ko je kmet bob sejal, izraste sicer bobovina neizmerno dolga, pa brez štročja. Žalosten in nevoljen vzame kmet koso, da bi bobovino pokosil. Rojenica pa se ga usmili in reče: »Ne kosi je, ampak piplji jo, kadar bo zrela.« In res, ko je bobovina dozorela, jo popipljejo, in celo steblo bilo je polno debelega zrnja.

Neka Rojenica je zahajala v kmečko hišo na posteljo spat, pa ko vidi, da gospodinji ni všeč, ji da klopčič ter reče: »Ta klopčič ti dam, zato ker sem hodila na tvojo posteljo spat, pa nikdar ne smeš reči, »da bi le že bil skoraj konec in tudi o koncu ne smeš nikdar govoriti, kadar boš iz tega klopčiča nit motala.« Dokler ni konca imenovala, se je zmiraj izmotavala lep preja. Enkrat pa reče gospodinja: "To je vendar čudno, da iz tega klopčiča ni nikdar konca«; in čuda! Prav tedaj je iztekel konec.

Prerokovale so tudi Rojenice nekemu fantičku pri porodu, da se bo obesil, kadar bode enajsto leto nastopil. Starši so se silno prestrašili in premišljevali so, kako bi svojega otroka oteli hude osode. Naučili so fantička, da naj vsako delo začne v Božjem imenu. Ko je prišla njegova ura, reče: "Zdaj se pa grem obesit v Božjem imenu«, - vzame vrv ter gre v goščavo. Tukaj priveže vrv za vejo, in ko si zanjko nastavi, pravi: "Zdaj se bom pa obesil v Božjem imenu.« Pa vrv se mu utrga. Zopet si jo zaveže in si dene zanjko na vrat, pa zopet se utrga vrv. Še tretjikrat poskusi, pa tudi zdaj se mu utrga vrv, če lih je bila jako močna. Med tem mu ura mine, in on se povrne zdrav in vesel domu.

(Vir: Pohorske pripovedke. V slov. bistriški okolici nabral Lovro Stepišnik, mlinar. Kmetijske in rokodelske novice 22 (28) 1864: 227-228.)

\section{Bajke o gradiš̌u.}

(Vir: Tomažič, 1942: 108-116.) 


\section{Ančnikovo gradišče (zelena kača z zlato krono)}

$\mathrm{Na}$ skrbno izbranem delu tinjskega Pohorja, na $750 \mathrm{~m}$ visokem strmem pomolu tik nad sotesko Bistrice, severno od Jurišne vasi, leži poznoantična utrjena postojanka, poimenovana Ančnikovo gradišče. Ustno izročilo pravi, da Pohorec za nič na svetu ne bo šel na gradišče, potem ko sonce zaide. Menda tam straži svoj zaklad zelena kača z zlato krono na glavi in gorje tistemu, ki se ji približa. Kača ima lahko obliko zmaja ali pa celo tigra.

Na samem pomolu gradišča so prepadne skale, v njih so železna vrata, ki so del rova, po katerem prideš z Ančnika v Bistriški grad, za njimi pa so skriti velikanski zakladi,

Nedaleč stran od gradišča, na bližnjem travniku, pravijo, se včasih sliši votel odmev, ko voz zapelje čez določen del ceste. Tudi tukaj naj bi bil rov. Še danes je živa tu zgodba o divji jagi.

Nekoč sem slišal, da je lovec tam streljal na zajca, ta pa je na njegovo začudenje začel rasti in se množiti pred njegovimi očmi. Lovec je v strahu pobegnil in kmalu umrl.

(Vir: Gulič, 2006, 32.)

\section{Ančnikovo gradišče (voz se je prevrnil)}

$\mathrm{Na}$ Tinju so poznali veliko zgodb o Ančnikovem gradišču. Tam so ljudje videvali ognje in druge prikazni. Nekemu drvarju, ki je ponoči peljal z vozom hlode, so konji podivjali, ko je peljal mimo Ančnikovega. Voz se je prevrnil, konji so mu ušli in jih je našel doma. Drvarček pa še sam ni vedel, kako je prišel domov.

Ančnikovo gradišče ima svoje moči, nedostopnost. Spomnim se tudi pripovedovanja, da so na previsni skali, na jugovzhodni strani, ljudje opažali železna vrata, za katerimi naj bi bil hodnik. Nikoli pa se ni nihče povzpel - to bi moral z alpinistično opremo - da bi ta vhod lahko videli. Notri naj bi bila kača, ki je čuvala Ančnikove zaklade. To naj bi bila zlatnina, zaboj zlatnikov, ki jih je nekdo tam sesul od strahu, ko je tam preko peljal te zlatnike. Od strahu je vse skupaj spustil in zaklad je tam ostal. Franc Šega (Prednikov) je poznal teh zgodb še in še. Ančnikovo gradišče pa se imenuje zato, ker je ta svet last kmetije Žerjavovih, po domače Ančnikovih. Hišnemu imenu pri nas pravimo "comen«. Tudi danes bi vaščani znali povedati veliko zgodb o Ančnikovem gradišču. Veliko so tudi prebrali iz knjige Jožeta Tomažiča.

(Vir: Arhiv ISN ZRC SAZU. Povedal Stane Gradišnik. Posnela Barbara Ivančič Kutin, 16. 1. 2018, Urh na Pohorju.)

\section{CERKEV SV. URHA}

\section{Cerkevsv. Urha}

Pri Urhu pravijo, da so ponoči zlobci kradli pašo. V̌̌asih se je tod okoli podila divja jaga in takrat je pokalo, lajali so psi in hud veter je lomil drevesa. Ker vemo, da je bil sv. Urh tudi zaščitnik tkalcev, lahko omenim še zgodbo o tkalcu lanu, ki je hodil mimo cerkve v krogu uro in pol. Šele zvonjenje cerkve na Šmartnem ga je odrešilo čarovnije. 
Tudi območje med Urhom in Šmartnim je bilo nekoč močno pod vplivom vraževerja. V močniku, majhni jasasti planoti malo za naseljem Urh, ob reki Bistrici, naj bi bila v srednjem veku živela čarovnica, ki je ponoči hodila na lov in si svetila z raznobarvnimi lučmi.

(Vir: Gulič, 2006: 47.)

\section{Skerbijekova kapela, cerkev svetega Urha in mogočna lipa}

Stegnetova (Skerbijekova) kapela je zelo stara zgradba, morda je bila zgrajena že pred cerkvijo svetega Urha v bližini, ki je iz 16 stoletja. Kapela je postavljena na vodni izvir. To je zelo dobra, zdravilna voda, predvsem za zdravljenje oči. Najmanj 300 let je že znano, da so sem prihajali ljudje po vodo, ker so verjeli, da je zdravilna za umivanje in za pitje. Ljudje iz doline še zdaj prihajajo in si jo natakajo, ob kapeli je zdaj vodnjakec in pipica.

Nedaleč stran na jasi sredi gozda stoji cerkev svetega Urha. Včasih je bila to božjepotna, romarska cerkev. V njej je več oltarjev, med njimi tudi zelo redek, če ne edini oltar svete Afre v Sloveniji. To je tabelni oltar, ki je do danes že skoraj povsem segnil, saj je bila v zadnjem času obnovljena samo zunanjost cerkve. Ljudje so sem množično prihajali na romanje okoli 17. julija. Takrat so natočili vodo, šli so k maši, potem je bila še veselica, na kateri so jedli, pili in plesali. Ob cerkvi je stala ogromna lipa. V njeni krošnji je bil postavljen oder, na katerega se je prišlo po lestvi. Tam so igrali muzikantje. Jaz te lipe nisem videl, prišel sem 3 leta prepozno, saj jo je leta 1971 podrl vihar (slika te lipe je v knjigi 100 lip na Slovenskem). Na teh veselicah je večkrat prišlo tudi do prepirov in pretepov med rivalskimi obiskovalci, največkrat med Čogli in Čebulaki, kot so šaljivo imenovali Šmarčane in Tinjčane. Bile so tudi smrtne žrtve, ko je kdo koga zaštihal ali udaril s planko, ki jo je utrgal s plota. Zaradi tega je škof ukinil božjo pot, od takrat ni bilo v lipi ne muzikantov in spodaj ne mrtvih. To je zapisano v župnijski kroniki. Mi je pa pravil stari dedek pri Anjelih po domače, sicer se je pisal Smogavec, da je prav on v štor podrte lipe vsadil novo lipo, ki se je tudi prijela in je zdaj že kar košato in zajetno drevo.

(Vir: Arhiv ISN ZRC SAZU. Povedal Stane Gradišnik. Posnela Barbara Ivančič Kutin, 16. 1. 2018, Urh na Pohorju).

TRIJE KRALJI

\section{Nočni lovec in lesni mož}

(Vir: -c-. (Davorin Trstenjak?), Pohorje. Zemljepisno-narodopisna črtica II. (Konec). Ljudski glas (Ljubljana) 3(15), 5. 9. 1884: 59.)

\section{Urškin križ in sezonski delavci}

Pod Velikim vrhom je ženska, ime ji je bilo Urška, obnemogla. Snežni metež jo je presenetil in je zmrznila. V spomin so ji postavili križ. Bila je iz Okoške gore v bližini Oplotnice. V nahrbtniku je nosila hrano možu v Jagerske peči - koruzni zdrob, moko, slanino. Ti holcarji so namreč cel teden 
živeli v gozdu v lesenih barakah. Grof Windischgraetz namreč ni imel takih naselij kot Attems (Kurjo vas in ostale holcarske zaselke). Ti delavci so imeli v bližini delovišča lesene barake (bajte), največkrat pokrite z drevesno skorjo. Notri je bil gašperček in so sami kuhali. Največkrat žgance z ocvirki, zelje, močne jedi. To se je dnevno ponavljalo. Pa moko kuhano in zabeljeno, t.i. belo župo z ocvirki; iz moke so izdelali forfle, grudice. Jaz sem še videl te barake pri Mrzlem studencu blizu Osankarice. Še dedek in tudi oče moje žene so živeli na ta način.

(Vir: Arhiv ISN ZRC SAZU. Povedal Stane Gradišnik. Posnela Barbara Ivančič Kutin, 16. 1. 2018, Urh na Pohorju.)

\section{Kako so šli po kolenih do Treh kraljev in zakaj ime Oplotnica}

Neko leto je bila strašanska suša, da je razpokala zemlja. In so ljudje šli romat za dež k svetim Trem kraljem. Pri tisti kapelici so se zbrali iz kebelškega kraja in iz tinjske fare. Od tam so šli po kolenih do svetih Treh kraljev do cerkve in so molili za dež. Tri dni za tistim je pa začelo deževati. Toliko je bilo dežja, da je vse odneslo. Tam, kjer je Oplotnica, je bil prej zaselek in samo ena hiša, ob enem plotu je ostala. In tako je Oplotnica dobila ime. Ko smo pa mi bili pastirji, pa smo o tej kapelici poslušali, da teče voda spodaj. Ni se videlo potoka, le slišalo se je vodo. Danes pa se vode ne sliši več.

(Vir: Pripoveduje Anton Smogavc, vodič in predsednik KUD Kebelj. Kot na Pohorju, 19. 4. 2017. Zapisala Barbara Ivančič Kutin, s kamero posnel Miha Peče.)

\section{Cerkev sv. Trije kralji}

To je le cerkev pa hotel, to je ledinsko ime, ni ime kraja. Je zgodba v zvezi s tem. So dvojni Trije kralji. Eni so nekje pod Bočem eni pa tu. In so nekoč nekoga ujeli, med vojno ali kaj $\neg$ nisem si dobro zapomnil - dali so mu tisto okovje gor na noge, pa je šel peš od spodnjih Treh kraljev tu gor. In ko je prišel tu gor, mu je okovje razpadlo na nogah. Nekaj takega je bilo, to bi še moral preveriti.

(Vir: Pripoveduje Anton Smogavc. Vodič in predsetdik KUD Kebelj. Kot na Pohorju, 19. 4. 2017. Zapisala Barbara Ivančič Kutin, s kamero posnel Miha Peče.)

\section{ČRNO JEZERO}

\section{Vehtra baba I}

(Vir: Avstro-ogrska monarhija v besedi in podobi: Slovenci. 1, Stajerska, Porabje in Prekmurje, Koroška. Ljubljana: Založba ZRC, ZRC SAZU, 2016, 52.)

\section{Vehtra baba II}

(Vir: Pajek 1884: 2, Vehtra baba.)

\section{9. Črno jezero na Pohorju}

Tam, kjer je danes Črno jezero, je nekoč stala mogočna domačija ponosne in brezsrčne gospe Agnes, ki je ukazovala po vsem pogorju in imela rudnike ter steklarne za svojo last. Njen sin ni bil nič manj ošaben kot ona. Ko je nekoč neki popotnik v vrtu odtrgal nekaj češenj in je v izviru hotel potešiti 
žejo, ga je fant nagnal s poplavo zmerljivk in ko je ob tem padel v lužo, je zatožil popotnika materi. Gospa Agnes je pred očmi lačnega popotnika z belim pšeničnim kruhom ribala umazanijo s sinkove obleke, a za prošnje starca je bila gluha. Starec ju je preklel in izginil.

Kmalu nato so se znad Velike Kope zgrnili težki oblaki, hudi neurje se je razdivjalo nad domačijo. Voda se je dvigala vse višje in višje in poplavila dvorišče, hišo, polje in vrt. Še danes je tam mračna voda, v kateri niti ribe ne morejo živeti. Le odvratni urhi bivajo tam.

(Vir: Schlosser 2015 (1956), št. 36.)

\section{O Vetrihu, Vetronu}

Na Pohorju je jezerce, mužnat kraj. Pravi se mu černa mlaka, černo jezero. Ako vanj vržeš kamenček, razjeziš hudega duha Vetriha ali Vetrona; in hitro ti napravi veter, blisk, grom in točo. V staroteržki fari so še kmetje, kteri se pišejo Vetrih.

(Vir: Slovenski glasnik (Celovec) 5 (4), 1. 4. 1860: 108.)

\section{1. Čep, ki je zadrževal vodo v Črnem jezeru}

Črno jezero je umetno, izdelati ga je dal grof Windischgraetz. Govoril sem še z očetom moje žene, ki je o tem znal veliko povedati. Okoli leta1880 so ga naredili kot akumulacijsko jezero za spuščanje dodatne vode po riži. Vodo so spuščali prek jezovne pregrade. Če so rabili dodatno vodo, so odprli čep dolge lesene prelivne naprave. Ta čep sem našel, ko smo leta 1993 obnavljali jez in izdelali kovinsko prelivno napravo z zapornimi ventili. Čep ima premer $20 \times 20 \mathrm{~cm}$, je štirioglat. Zgoraj ima kovinski prstan, da so ga lahko dvigali in spuščali. Ta čep je zdaj shranjen v Gradu v Slovenski Bistrici. Leta 1993 je v jezeru naenkrat vode zmanjkalo. Zgnila je lesena prelivna naprava in voda je ušla.

(Vir: Arhiv ISN ZRC SAZU. Povedal Stane Gradišnik. Posnela Barbara Ivančič Kutin, 16. 1. 2018, Urh na Pohorju.)

\section{ŠMARTNO NA POHORJU}

\section{Povodni mož}

V Padenskem šumu, so pravili, da je bil povodni mož, je stanoval v tistem šumu Padenskem, ja v Padnikovem šumu, tam spodaj.

Potem so pa v Šmartnem v cerkvi svetega Martina nove težke zvone dobili, tiste, ki so jih potlej Nemci vzeli.

Tistih zvonov pa povodni mož ni prenašal, pa je ven iz onega šuma odšel. Ni prenašal onih zvonov, ko so pa tako pregrkovali, da se je tako močno v dolino po tem grabnu dol slišalo, ko so toti težki zvoni doneli, da to mu pa ni pasalo. Se je potem pa selil ven iz tistega jezera pod Padnikovim šumom tisti povodni mož, kam je šel pa ne vemo.

(Vir: Arhiv ISN ZRC SAZU. Povedala Martin Lunežik in Tone Pečovnik. Posnela Barbara Ivančič Kutin, 17. 1. 2018, Šmartno na Pohorju.) 


\section{Orfej na cerkvi sv. Martina $v$ Šmartnem}

Cerkev sv. Martina ima najstarejše romanske freske na Slovenskem. Njena zanimivost pa je tudi kamnit relief Orfeja iz rimskih časov na zunanji steni. Orfej je danes že okrušen, obstaja pa kakih 50 let stara fotografija, na kateri ima še cel obraz. Kako je le-ta prišel na fasado cerkve, je bržkone zanimiva zgodba. Ko so gradili prvotno cerkev, so rimsko nagrobno ploščo z reliefom Orfeja uporabili za gradbeni material: ker je bila cerkev romanska, so kamen obtesali v polkrožno obliko - luneto, ter ga uporabili za romanski portal. Lice nagrobnika, to je relief z Orfejem, so obrnili v steno, da se ga ni videlo, saj v zgodnjem krščanstvu motivi iz poganskih časov niso bili zaželeni. Leta 1836 so cerkev podaljšali, takrat so steno, kjer je bil vhod, podrli. Romanski portal ni bil več aktualen in so napravili novega. Ker je bil to čas, ko so že znali ceniti rimske ostaline, so dali rimski nagrobnik s podobo Orfeja vzidati na vidno stran fasade, v podaljšek cerkve.

In kaj bi lahko potrdilo to zgodbo: če je bil kamen na prvotni cerkvi res nad vhodom, bi zadaj gotovo našli romanski relief - križ, jagnje ali pa kak Martinov simbol; to bi bilo zelo pomembno, odkritje, saj imamo v slovenski romaniki le malo kamnoseških izdelkov. Pa ne le to, s tem bi prišli tudi do popolnih informacij o podobi romanske cerkve: imamo širino, dolžino, višino, imamo romanska okna in dobili bi še romanski portal, kar bi bil eden redkih primerov (edini?) na Slovenskem.

(Vir: Arhiv ISN ZRC SAZU. Povedal Ferdinand Šerbelj. Zapisala Barbara Ivančič Kutin, 11. 5. 2018, Ljubljana.)

\section{Vile v Grdišnikovem mlinu}

Potlej je bilo, pri totem Grdišnikovem mlini tam pri Grdišnikovem mlini tam straši, zmerom straši v tistem Grdišnikovem mlini. Te je pa bila steza mimo mlina, tam so ljudje hodili skoz... Te je pa te bilo - ko je moja žena je te bila še poleg matere, so šle zvečer domov. Je bila ona, komaj bila stara, enih 5, 6 let... So šle zvečer dol, ponoči jo že tam tema dobila, pa te mimo tistega mlina gre, tam ko so pravili, da straši not - ko so pa mimo šle, so pa te čule, da mlin gre, ne... da mlin laufa, ropota not, ne... pa luč not v mlini bila... so bile vile not v mlini. So hotele it gledat te vile, so hotele odpret vrata, pa so vrata bila zaklenjena, ne... niso mogle not v mlin, kak pa tak, kak pa tak - ko pa se je zaklenilo, so te šli gledat gor, kaj pa če je kateri škandal naredil nalašč, pa vodo v žlejb te potisnil, pa da zdaj prazen mlin laufle not. Mlin brez vode. So pa šli gledat gor, tam ko je voda sem prišla, ... po tistem žlajbi, sem pritekla pa dol...

Smo šli gledat te, če voda teče - te pa ni voda tekla, je tista bla (?) ... to pa te ni, ne teče voda dol na mlin, mlin pa laufle dol, pa tja jih je bilo celo strah... ona, žena te pravila, materi za kiklo se primem, pa smo šle naprej pa bežat, ne...

Včasih je kateri mlel not, pa je luč seboj nosil, to petrolejko, da je dol mlel.

(Vir: Šmartno na Pohorju, 17. 1. 2018, ok. 10. ure pri g. Pečovniku v kleti, kjer ima družabni prostor. Povedala Martin Lunežnik (r. 1934) in Tone Pečovnik (r. 1950), Šmartno na Pohorju. Dokumentirala Barbara Ivančič Kutin.) 


\section{ŠETOROV MLIN IN HUDIČEVO KORITO}

\section{Hudičev mlin}

Neki kmet si je zelo želel mlina, njegova denarnica pa je bila žal prazna. Pa se je odpravil k hudiču. In čez noč je bil mlin postavljen.

"Kaj želiš za to? « je vprašal kmet in se že zbal za svojo dušo, a hudič je odgovoril: „Nič drugega, kot da me vsako noč med enajsto in dvanajsto pustiš mleti v tvojem mlinu!«Kmet se je strinjal. Noč za nočjo je praznil mlin in hudič je točno ob enajstih pričel svoje delo. Iz mlina je prihajal tako mogočen hrup, da je kmet komaj zdržal. Kmalu se je zbal za svoj mlin in je premišljeval, kako bi se znebil hudiča. Neki prijatelj mu je svetoval, naj mlina nič več ne prazni, temveč naj nadaljuje delo; in da se bo vse drugo že uredilo. To je kmet tudi storil. Ko je prišel hudič, je kmeta hudo ozmerjal, kajti njegov čas je že nastopil. Kmet pa je rekel, naj mu raje pomaga pri spravljanju. »Pridrži tole vrečo, pa bo mlin kmalu čist!« Hudič je z rokami zgrabil za rob vreče in jo držal z vso močjo, kajti bila je vse težja. Ko je bila končno do vrha napolnjena, so se dolgi hudičevi kremplji tako globoko zarili v platno, da se ni mogel več osvoboditi. Začel je tarnati, kar je bilo kmetu po godu. »Pomagal ti bom,« je rekel, »a najprej morava vrečo vpeti v primež.« Pokorno je hudič s svojim tovorom odšepal so skobeljnika. Ko pa se je napravil, da vrečo dvigne v primež, ga je kmet sunil, da se je vreča odkotalila na stran in je hudič sam pristal v primežu. Kmet je nemudoma privil vijak: in hudič je bil ujet. Ko je hudič videl, da se ne more več osvoboditi, je začel kmeta rotiti za prostost. „Osvobodil te bom, « je rekel kmet, "a moraš mi obljubiti, da se nikdar več ne vrneš v mlin!« Govoril je počasi in ob vsaki besedi je malo privil primež. A hudič ni hotel popustiti. Krvavo se je potil in hudičevo jokal, korito je že počilo, a njegove roke so bile še zmeraj zadrte v vrečo. Kmet je še naprej privijal vijak in hudiču je gonilo rinilo vse globlje v život. "Torej hudič, kako si se odločil?« vpraša kmet. Obupani hudič glasno zarjove in privoli v ponudbo.

Kmet je držal besedo. Spustil ga je iz mučilne naprave, izvlekel kremplje iz platna in hudič je izginil v temni noči. Kmet se je zelo veselil. Drugi dan je spet delal pozno v noč, nato pa se je usedel $\mathrm{k}$ počitku na klopco pred mlin. A kdo je spet prišel, k oje ura odbila enajst? Ponovno hudič. Kmet je skočil v mlin, vzel primež in se je z njim postavil pred vrata. Ko je hudič spet zagledal mučilno napravo, je pobegnil in se ni več prikazal.

(Vir: Schlosser 2015 (1956), št. 75.)

\section{6. Šent}

Kraj rečice Devine v Bistriški župniji na jugozahodnem vznožju Pohorja so se svoje dni prepirali hudi duhovi zaradi mlinarja, po katerega so prišli, ker se je preveč držal načela: „Vsakemu pol zmlete moke«.

Zlodej je rekel: „Moj je!«

Div je trdil: „Moj je!«

In ker se nista mogla zediniti, čigav bo mlinar, je prišel Šent z brega. V roki je imel sekiro, in na eno nogo je šepal ali šentoval, zato so mu tudi rekli Šent. Vzdignil je ostro sekiro in rekel:

„Moj je, jaz ga bom sodil!« 
Div in Zlodej sta se prestrašila njegove sekire in sta hitro spustila mlinarja. Še dandanašnji se reče temu kraju, kjer je stal mlin, Zlodjev mlin, rečica pa se imeuje Devina.

O Šentu pripovedujejo tudi, da je najbolj nevaren na sveti večer. Tiho prišanta k hramu (hiši) in odžene svoje služabnike*. Ti morajo prek velike vode plavati, potem jih pa v volke spremeni. Dvanajstere noči po božiču se torej vele volčje noči, ker je takrat Šent na oblasti.

*Šentovi služabniki so tisti ljudje, ki so se rodili z določenimi znamenji po katerih so včasih sklepali, da so volkodlaki. Verjeli so, da se občasno spreminjajo v volkove.

(Vir: Pajek, 1884: 226.)

\section{Hudičevo korito}

Tam pri Lazniku je Hudičevo korito. To je skala, v kateri je bila vedno voda, čeprav tam ni nobenega izvira. In so rekli stari ljudje, da je tja hodil hudič konje napajat, ker je bila tam stalna voda. Mimo tega korita je včasih peljala stara pot, po kateri so vozili furmani: ko so bili polni, so šli po daljši poti, ki je bilj položna, nazaj, ko so bili prazni, pa so šli mimo Hudičevega korita, ker je bila pot bolj strma. In ko so šli nazaj, so stalno tisto kavlo rukali, pa so tisto kavlo včasih ferderbali pri tistem koritu, ko je bila tako ven skala in so se vanjo zadevali. Pa so hudiča kleli, ne! So ga kleli hudiča. To pa je hudiča razjezilo, je pa udaril po tisti skali tako, da je korito počilo in je voda ven stekla. Fertik! Zdaj pa je korito še, vode pa ni več nobene. To je še ena stara žena pravila.

(Vir: Arhiv ISN ZRC SAZU. Povedala Martin Lunežnik in Tone Pečovnik. Zapisala Barbara Ivančič Kutin, 17. 1. 2018, Šmartno na Pohorju.)

\section{TINJE}

\section{Vile (Veliko Tinje)}

Blizu Malega Tinja na poti proti Radkovcu je granitno območje, zelo nedostopno, in tam je velika razpoka oziroma jama, jaz sem jo videl. Območje se imenuje Juhartove Jeruzele. Zgoraj je Juhartova kmetija, kjer so lepi travniki, pod kmetijo v previsnem skalovju pa je jama. In tam je bilo domovanje pohorskih belih vil, jeruzelskih vil. Bile so zelo dobrohotne te bele žene. Bile so belo oblečene in so povsod sodelovale. Pomagale so pri kotitvi živali, pri boleznih živine, pojavljale so se pri rojstvu otrok, pomagale so na polju, pri pletvi, žetvi. Ljudje so se obračali nanje.

Potem pa je prišlo do zlobe, nekdo jim je slabo storil, ko so prišle na obisk. Ne vem, kaj je naredil, ali jih je odslovil ali jih je nagnal ali je preklinjal. Takrat so izginile in se nobena nikoli več ni vrnila. Do te jame pridete, če greste iz Velikega Tinja na Malo Tinje in še naprej proti Radkovcu, čez potok navzgor.

(Vir: Arhiv ISN ZRC SAZU. Povedal Stane Gradišnik. Posnela Barbara Ivančič Kutin, Urh na Pohorju, 16. 1. 2018.) 
29. Oče svojega sinčka proda, $A T U 810$.

(Vir: Besednik (Celovec), 5. 8. 1869: 115. Na Pohorji nabral Lovro Stepišnik.)

\section{Vile v Juhartovih Jeruzelah (Malo Tinje)}

Blizu Malega Tinja na poti proti Radkovcu je granitno območje, zelo nedostopno, in tam je velika razpoka oziroma jama, jaz sem jo videl. Območje se imenuje Juhartove Jeruzele. Zgoraj je Juhartova kmetija, kjer so lepi travniki, pod kmetijo v previsnem skalovju pa je jama. In tam je bilo domovanje pohorskih belih vil, jeruzelskih vil. Bile so zelo dobrohotne te bele žene. Bile so belo oblečene in so povsod sodelovale. Pomagale so pri kotitvi živali, priboleznih živine. Pojavljale so se pri rojstvu otrok, pomagale so na polju, pri pletvi, žetvi. Ljudje so se obračali nanje.

Potem pa je prišlo do zlobe, nekdo jim je slabo storil, ko so prišle na obisk. Ne vem, kaj je naredil, ali jih je odslovil ali jih je nagnal ali je preklinjal. Takrat so izginile in se nobena nikoli več ni vrnila. Do te jame pridete, če greste iz Velikega Tinja na Malo Tinje in še naprej proti Radkovcu, čez potok navzgor.

(Vir: Arhiv ISN ZRC SAZU. Povedal Stane Gradišnik. Posnela Barbara Ivančič Kutin, 16. 1. 2018, Urh na Pohorju.)

\section{Vragova peč}

$\mathrm{Na}$ stari tinjski cesti za vprežno živino - ta cesta je vodila v Tinje nekoliko drugače kot je speljana današnja cesta. Franc Šega iz Jurišne vasi je pripovedoval, da je šel po tej cesti domov. V dolini je nekaj spil in tam pri Vragovi peči je videl neke sence. „Eh, saj ni nič,« si je mislil, in ko je prišel mimo te skale, ga je tam nekaj močno prestrašilo. »Morda je bil sam zlodej, « je glasno govoril. Je izgubil klobuk in bežal domov. Drugi dan je šel iskati klobuk in je bil na pečini, na skali. Se je vrag igral z njegovim klobukom?

(Vir: Arhiv ISN ZRC SAZU. Povedal Stane Gradišnik. Posnela Barbara Ivančič Kutin, 16. 1. 2018, Urh na Pohorju.)

\section{KEBELJ}

\section{Roparski vitezi (Zajčev in Zbegov grad)}

V Keblju imamo dve razvalini. Ena je graščina pod Kebljem - Zbegova graščina, nad Kebljem pa je Zajčev grad. Izročilo pravi, da naj bi bila graščina in grad med sabo povezana s podzemnim rovom. Bila sta dva viteza, ki sta pod pretvezo, da bosta mimoidočim pomagala, ropala ljudi. Tam mimo je namreč peljala romarska pot. Posamezniki, romarji so nosili darila k Mariji v Puščavo. Ta dva viteza sta imela plačane delavce, ki so ogovorili mimoidoče in jih nadlegovali. Takrat sta na konju prihrumela viteza in jim navidezno pomagala tako, da sta romarje zvabila v graščino. Tam so jih oropali, jih poslali v rov, ki je bil povezan z Zajčevim gradom. Zajčevemu gradu pravijo tudi Mučeniški stolp, kajti iz te ječe več ni bilo izhoda. Zbrali so se domačini, ki so poskušali uničiti ta dva viteza. Zažgali so grad, viteza sta bila notri v gradu, $v$ graščini in sta dobesedno zgorela. 
Kasneje sta se pojavila dva okoliška kmeta, ki sta poskušala najti te zaklade. Zaobljubila sta se Mariji, da če bosta našla zaklad, da bo polovico zaklada pripadalo njej, Mariji. Natovorila sta voz, a Marija ni od tega dobila nič, saj sta si premislila. Ko sta vola vlekla zaklad po strmini, je voz zgrmel v prepad. Kaj je bilo z zakladom, pa zgodba ne govori.

Nekateri so pripovedovali, da naj bi rov res obstajal, drugi pravijo, da je to samo v bajki, tretji pa menijo, da je ta rov že zakopan (zasut). Prave resnice o tem pa ne vemo.

Pravijo, da ima cerkev svete Marjete v Keblju najlepšo prižnico v Konjiški dekaniji. Z njo je povezana tudi zelo ganljiva zgodba. V neki družini je bile ena zelo pobožna hčer. Starši tega niso odobravali in so jo zelo mučili in na koncu je bila obglavljena. Cerkev je stara iz leta 1251, bila pa je temeljito obnovljena: na novo prekrita, popravili so kor in naredili novo fasado.

(Vir: Arhiv ISN ZRC SAZU. Povedala Angela Šalamun. Posnela Barbara Ivančič Kutin, s kamero posnel Miha Peče. Ista zgodba je v: Tomažič, 1943: 113-127, „Marijin zaklad».)

\section{Vas Kolonija}

Od leta 1946 do 1950 je bilo zaposlenih v kamnolomu Cezlak okrog 550 delavcev. Zato se je pojavila potreba po stanovanjih za zaposlene. Vodstvo kamnoloma se je odločilo, da pol kilometra pred Cezlakom uredi vas Kolonija. Bil je domačin Gašper, ki je nasprotoval gradnji na tem mestu, razmere so mu bile namreč dobro znane. Nihče ga ni upošteval, celo na zagovor so ga poklicali, in tako se je začela gradnja te vasi. Iz Nemčije je prispelo 5 lesenih hišs, zgradili so eno iz opeke in stanovanjski blok. Čeprav je za stanovanjski blok rekel takratni kebeljški župnik, da ni bil nikoli dokončan, saj mu je manjkala fasada.

Prišlo je obdobje, ko je na tem območju zelo močno deževalo; takrat se je na pobočju na levi strani vasi začel pojavljati plaz, ki je bil dolg približno $500 \mathrm{~m}$, in širok do 1 metra. V globini tega jarka se je slišalo šumenje vode, voda je drla tudi izpod temeljev stanovanjskega bloka. Stanovalci pa tudi vodstvo Cezlaka so bili zelo zaskrbljeni. Vodstvo Cezlaka je poklicalo uradne inštitucije iz Ljubljane, da so proučili razmere in padla je odločitev: ljudi takoj izseliti! Prebivalci so si zatočišče poiskali pri prijateljih, znancih, sosedih, dve družini sta se preselili v sindikalno dvorano v Cezlaku. Kasneje so dobili dolgoročne kredite in si v Oplotnici zgradili nove hiše, danes je tam Granitna ulica. Družine so bile zelo številčne. Zato so okoliški kmetje rekli: »To je Kurja vas: petelin kura in piščanci.« Nekaj žensk je bilo zaposlenih v Cezlaku, ostale pa s opravljale različna dela pri okoliških kmetih in tako prispevale nekaj v družinski proračun. Znamenitost tega bloka je bila, da je bila v kleti zgrajena krušna peč. Po vrstnem redu je vsak dan ena gospodinja pekla kruh v tej peči. Pozneje so to vas, Kolonijo, podrli in danes je tam spe Kuclov travnik.

Kulturno-umetniško društvo Kebelj je organiziralo srečanje rojakov in takrat so na tem mestu ob cesti postavili spominsko ploščo s posvetilom in vklesano podobo vasi.

(Vir: Arhiv ISN ZRC SAZU. Povedala Angela Šalamun. Zapisala Barbara Ivančič Kutin, 19. 4. 2018, Cezlaki.) 


\section{REFERENCE}

\section{LITERATURA}

Bacchilega, Cristina. 2007. Legendary Hawai' $i$ and the Politics of Place: Tradition, Translation, and Tourism. Philadelphia: University of Pennsylvania Press.

Bendix, Regina. 1989. Tourism and Cultural Displays: Inventing Traditions from Whom? The Journal of American Folklore 102 (404): 131-146. DOI: https://doi.org/10.2307/540676.

Cunta, Miljana, ur. 2019. Živa coprnija Pohorja in Istre: Izletipo poteh pripovednega izročila. [Living Magic of Pohorje and Istria: Trips Along the Paths of Lore.] Literarizacija pripovedi Dušan Šarotar, ilustracije Tina Dobrajc. Ljubljana: Beletrina.

Gunnell, Terry, ur. 2008. Legends and Landscape. Reykjavik: University of Iceland Press.

Hiiemäe, Reet. 2016. Narrative Maps of Danger as a Means of Subjective Protection. Etnološka tribina 39 (46): 176-186. DOI: https://doi.org/10.15378/1848-9540.2016.39.07.

Ivančič Kutin, Barbara. 2011. Živa pripoved v zapisu: Kontekst, tekstura in prekodiranje pripovedi Tine Kravanja iz Bavšice. Ljubljana: Založba ZRC, ZRC SAZU.

Ivančič Kutin, Barbara. 2017. Transformacije (slovstvene) folklore v sodobni kulturi: Krivopete v zgornjem Posočju in v Benečiji. Traditiones 46 (1-2):37-54. DOI: https://doi.org/10.3986/Traditio2017460102.

Ivančič, Kutin, Barbara. 2019. Tematske poti in drugi izkustveni pristopi pri obravnavi folklornih besedil v osnovni šoli. Jezik in slovstvo 64 (2): 95-108.

Ivančič Kutin, Barbara in Monika Kropej Telban. 2018. Ohranjanje nesnovne kulturne dediščine z lokalnimi pripovedmi v prostoru. Traditiones 47 (3): 103-115.DOI: https://doi.org/10.3986/Traditio2018470307.

Ivančič Kutin, Barbara in Monika Kropej Telban. 2021. Legends of Places as Part of the Sustainable Development of Regions. Folklore.ee 81: 157-178. DOI: https://doi.org/10.7592/FEJF2021.81.ivancic_kropej.

Koski, Kaarina. 2016. Discussing the Supernatural in Contemporary Finland: Discourses, Genres, and Forums. Folklore.ee 65: 11-36. DOI: http://dx.doi.org/10.7592/FEJF2016.65.koski.

Kropej Telban, Monika in Roberto Dapit. 2018. Čudežne pravljice slovenskih pokrajin: Čarobni svet princev in vilincev. Radovljica: Didakta.

Matičetov, Milko in Maja Bošković-Stulli. 1958. Dobra zbirka slovenskih pripovedk iz leta 1910 slabo izdana 1956: Paul Schlosser, Bachern-Sagen (Vorwort von Leopold Schmidt). Slovenski etnograf 11: 187-200.

Mencej, Mirjam. 2020. Čarovništvo - diskurz ali praksa. Studia mythologica Slavica 23: 137-158.

Slavec Gradišnik, Ingrid. 2014. V objemu dediščin. V: Interpretacije dediščine, ur. Tatjana Dolžan Eržen, Ingrid Slavec Gradišnik in Nadja Valentinčič Furlan, 8-24. Ljubljana: Slovensko etnološko društvo.

Šešo, Luka. 2020. Supernatural Beings of Belief Legends - Old Fears in a New Context. Studia Mythologica Slavica 23: 183-202. DOI: https://doi.org/10.3986/SMS20202311.

Štefan, Anja. 2019a. Knjigi na pot. V: Tristo zajcev: Najlepšse slovenske ljudske pravljice iz zapušcine Milka Matičetovega, ur. Anja Štefan, 239-254. Ljubljana: Mladinska knjiga.

Štefan, Anja, ur. 2019b. Tristo zajcev: Najlepše slovenske ljudske pravljice iz zapuščine Milka Matičetovega. Ljubljana: Mladinska knjiga

Valk, Ülo in Daniel Sävborg, ur. 2018. Storied and Supernatural Places: Studies in Spatial and Social Dimensions of Folklore and Sagas. Helsinki: Finnish Literature Society. 


\section{VIRI}

Brinar, Josip. 1933. Pohorske bajke in povesti. Ljubljana: Učiteljska tiskarna. (Ilustracije: Maksim in Oton Gaspari.)

-c-. 1884. Pohorje. Zemljepisno-narodopisna črtica II. (Konec). Ljudski glas (Ljubljana) 3 (15), 5. 9.: 59.

Črno jezero. Pravljice. Besednik 2 (24), 25. 12. 1870: 189.

Črno jezero na Pohorju: Pravljce iz Slovengraškega okraja, št. 5. Zapisal Fr. V. Popotnik 6 (7), 10. 4. 1885: 109-110.

Pohorski. Fr. 1859. Slovenske narodne pripovedke o velikanu Vouvelu. Kmetijske in rokodelske novice 17 (11), 16.3.: 86-87.

Gričnik, Anton. 1995. Noč ima svojo moč Bog pa še večjo: Pohorje pripoveduje. Ljubljana: Kmečki glas.

Gričnik, Anton. 2015. Coprnice so vflaši: Tisoč in ena ljudska pripoved spodročja med Pohorjem in Halozami, med Celjem, Mariborom in Ptujem. Maribor: Mariborska literarna družba.

Gulič, Andrej. 2006. Zgodovinska podoba slovenskobistriškega Pohorja od prazgodovine do 20. stoletja. Diplomsko delo. Ljubljana: Filozofska fakulteta.

Hudales, Oskar. 1968. Zlati krompir: Pohorske pripovedke in pravljice. Maribor: Založba Obzorja.

Miklavec, Filip (psev. L. Vrhovski). 1903. Truojni odgovor: Pohorska narodna pripovedka. - Zapisal L. Vrhovski. Dom in svet 16 (4): [zadnja platnica].

O Vetrihu, Vetronu. Slovenski glasnik (Celovec) 5 (4), 1. 4. 1860: 108.

Pajek, Josip. 1884. Črtice iz duševnega žitka štaj. Slovencev. Ljubljana: Matica slovenska.

Sann, Hans von der. 1911. Der Schwarze See am Bachern. V: Sagen aus der grünen Mark. Graz.

Schlosser, Paul. 1912. Der Sagenkreis der Poštela: Ein Blick ins Bachernreich. Marburg a. d. Drau: Museumsverein in Marburg.

Schlosser, Paul. 1956. Bachern-Sagen. Wien: Österreichisches Museum für Volkskunde.

Schlosser, Paul. 2015 (1956). Schlosserjeve Pohorske pripovedke. Maribor: Zavod Gremo na Pohorje.

Stepišnik, Lovro. 1864. Pohorske pripovedke: V slov. bistriški okolici nabral Lovro Stepišnik, mlinar. Kmetijske in rokodelske novice 22 (28), 13. 7.: 227-228.

Stepišnik, Lovro. 1869. Oče svojega sinčka proda: Na Pohorji nabral Lovro Stepišnik. Besednik (Celovec) 13, 5. 8.: 115 .

Škrinjar, Vida.1999. Cezlak - moja vas. Seminarska naloga. Slovenska Bistrica: Ljudska univerza.

Terstenjak, Davorin. 1859. Mytologične drobtine. Slovenski glasnik 2 (4), 1. 8.: 47-50.

Tomažič, Jože. 1942. Pohorske pravljice. Ljubljana: Konzorcij »Slovenica«.

Tomažič, Jože. 1943. Pohorske bajke. Ljubljana: Konzorcij »Slovenica«.

Tomažič, Jože. 1944. Pohorske legende. Ljubljana: Konzorcij »Slovenica«.

Tomažič, Jože. 2011. Pohorske pravljice (1942), Pohorske bajke (1943), Pohorske legende (1944). Bilje: Studio $\mathrm{RO}$ - Humar. 


\section{ARHIVSKI VIRI}

Milko Matičetov, terenski zvezek Pohorje, marec 1957. Povedal: Grabnarjev Gustl, Pohorje, Golavabuka, pr' Strmčnik, marec 1957. Arhiv ISN ZRC SAZU.

Milko Matičetov in RTV Slovenija 1967 (film): »Pri naših pravljičarjih III: Gustl Fišer - Grabnarjev, Legen pri Slovenj Gradcu.

Barbara Ivančič Kutin, tonski posnetki, Pohorje, 16. 1. 2018; 19. 4. 2018; Ljubljana, 11. 5. 2018.Arhiv ISN ZRC SAZU.

\section{LOCAL LEGENDS FROM THE POHORJE MOUNTAINS ABOVE SLOVENSKA BISTRICA: BETWEEN CULTURAL HERITAGE AND LITERALIZATION}

Various preconceptions are frequently associated with certain places or regions because a place is more than just a geographic location -it is also a site of memory and a venue for out-ofthe-ordinary events. In structuring an area from the perspective of narrative culture, one must take into account that narrativity is not static. Changes take place at both the diachronic and synchronic levels because these are strongly affected by the time and place; that is, the social and cultural environment in which people live. People that attach meaning to places create significant cultural and semantic regions, and these are also constituent parts of their identification processes. Sites of memory return to people's mental discourse, and telling stories about them influences cognition that expresses a particular view of the world. Narratives can therefore be located on a cognitive map of experiences.

To be able to place narratives in their locations, one must know various aspects of the local tradition (e.g., history, genre, and language) well. The overall diachronic and synchronic contexts must be taken into account, as well as the local population. Without these in mind, the local narrative culture is at risk of being simplified in an anachronistic and selective manner, and so it is important to involve experts in such projects. Institute of Slovenian Ethnology members participated in the European Interreg project Living Magic (Sln. Živa coprnija, Cro. Živa štrigarija, 2017-2019), which aimed to raise awareness of the narrative heritage of the Pohorje Mountains above Slovenska Bistrica and Croatian Istria by creating high-quality tourism and educational products. Our task was to find suitable narrative material to use as a basis for an artistic, literary, and aesthetically pleasing guide incorporating a writer's literary reinterpretation and quality illustrations. Stories from the oral tradition were inappropriate for more literary reading. The process of transferring oral folklore (the art of spoken language) into literature (written language) always necessitates a minor or major departure from the 
original (oral) form. In the Living Magic project, the professional responsibility was limited to the relevant material and recording the local tradition in the field, which is presented in the appendix at the end of the article.

Research has shown that both the etic and emic perspectives on narrative cultural heritage in the area must be taken into account because the local people themselves affect the development and existence of the narrative tradition, whether they preserve it, forget it, or create a new one.

When the project book - the guide with Dušan Šarotar's literary interpretations (Cunta 2019)_makes it into readers' hands, the published stories may have a similar impact as the stories published decades ago by Jože Tomažič and Josip Brinar. Their interpretations have gained a place in tradition. Heritage is about the "present past," which is always the product of current views of the past and cannot escape the grip of ideological or political interests, which has often taken place in recent times.

Doc. dr. Barbara Ivančič Kutin, ZRC SAZU, Inštitut za slovensko narodopisje, barbara.ivancic@zrc-sazu.si

Dr. Monika Kropej Telban, ZRC SAZU, Inštitut za slovensko narodopisje, monika.kropej@zrc-sazu.si 